\title{
Mesozoic reworking of late Archean lower crust in the North China craton
}

\author{
JIANG, N. ${ }^{1}, \mathrm{HU}, \mathrm{J}^{2}$
}

${ }^{1}$ Institute of Geology and Geophysics, Chinese Academy of

Sciences, jiangneng@mail.iggcas.ac.cn

${ }^{2}$ Institute of Geology and Geophysics, Chinese Academy of Sciences,hujun0620@126.com

Granulite terrains and xenoliths provide two direct ways of investigating the nature and evolution of the relatively inaccessible lower crust. The Hannuoba region of the northern North China craton is among the few localities where deep-seated xenoliths can be compared with exposed granulites. Lower crustal xenoliths from Tertiary Hannuoba alkali basalts show a large range in whole rock Sr-Nd isotopic compositions and extreme age diversity. Zircon populations of 2.5-2.7 Ga, 1.8-1.9 Ga and 80-160 Ma are present. The whole rock $\mathrm{Sr}-\mathrm{Nd}$ isotopic compositions for the Hannuoba lower crustal xenoliths fall within the range of the exposed granulite terrains. In addition, the late Archean and Paleoproterozoic zircon ages of the lower crustal xenoliths are also comparable with those of the granulite terrains which have a protolith age of $\sim 2.5 \mathrm{Ga}$ followed by metamorphic overprints at 1.8-1.9 Ga. Further investigation shows that most of the Mesozoic zircons in the Hannuoba lower crustal xenoliths either precipitated from partial melts derived from the late Archean lower crust or recrystallized from preexisting $\sim 2.5$ Ga grains. It demonstrates a late Archean lower crust beneath Hannuoba.

Voluminous 125-143 Ma intermediate-felsic magmatic rocks in the Hannuoba region have whole rock Sr-Nd isotopic compositions indistinguishable from those of the Hannuoba mafic lower crustal xenoliths. In addition, their magmatic zircons have Hf isotopic compositions comparable with those of the 80-160 Ma zircons from the Hannuoba mafic lower crustal xenoliths. Inherited zircons with $\sim 2.5 \mathrm{Ga}$ ages are common in these magmatic rocks. Combined with all data, it is suggested that most of the Hannuoba mafic lower crustal xenoliths can be best explained as residues left after partial melting of the late Archean lower crust that may be represented by the granulite terrain to produce the voluminous Mesozoic intermediate-felsic magmatic rocks.

Our proposed scenario can also be applied to the whole eastern NCC where widespread 120-140 Ma intermediatefelsic magmatic rocks commonly have $\sim 2.5 \mathrm{Ga}$ inherited zircons and their $\mathrm{Sr}-\mathrm{Nd}$ isotopic compositions are similar to the Hannuoba counterparts, suggesting derivation mainly from the late Archean lower crust and intense Mesozoic reworking of the ancient lower crust. 